\title{
Neogene seismites and seismic volcanic rocks in the Linqu area, Shandong Province, E China
}

\author{
H.S. Tian"1, ${ }^{1,}$ B.H. Zhang' ${ }^{2}$ S.H. Zhang ${ }^{3}$, M.Y. L $\ddot{u ̈}^{4}$ \\ ${ }^{1-4}$ Shandong Jianzhu University, Fengming Road, Lingang Development Zone, Jinan 250101, Shandong Province, \\ China \\ email addresses: ${ }^{1}$ tianhongshui@126.com; ${ }^{2}$ banghuazhang@163.com; ${ }^{3}$ zhangshenhe@sdjzu.edu.cn; \\ ${ }^{4}$ lmy123@sdjzu.edu.cn \\ * corresponding author
}

\begin{abstract}
The Yishu Fault Zone runs through the centre of Shandong Province (E China); it is a deep-seated large fault system that still is active. Two volcanic faulted basins (the Shanwang and Linqu Basins) in the Linqu area, west of the fault zone, are exposed to rifting, which process is accompanied by a series of tectonic and volcanic earthquakes with a magnitude of 5-8. Lacustrine sediments in the basins were affected by these earthquakes so that seismites with a variety of softsediment deformation structures originated. The seismites form part of the Shanwang Formation of the Linqu Group. Semi-consolidated fluvial conglomerates became deformed in a brittle way; these seismites are present at the base of the Yaoshan Formation. Intense earthquakes triggered by volcanic activity left their traces in the form of seismic volcanic rocks associated with liquefied-sand veins in the basalt/sand intercalations at the base of the Yaoshan Formation. These palaeo-earthquake records are dated around 14-10 Ma; they are responses to the intense tectonic extension and the basin rifting in this area and even the activity of the Yishu Fault Zone in the Himalayan tectonic cycle.
\end{abstract}

Keywords: seismite; seismic volcanic rock; Neogene; tectonic extension; Linqu

\section{Introduction}

Seismites are sediments that were affected by an earthquake when they were still incompletely consolidated, so that soft-sediment deformation structures (SSDS) were formed in them (Qiao et al., 1994; Du \& Han, 2000; Tian et al., 2003; Van Loon, 2014a, this issue). Both plastically deformed seismites with SSDS and seismites that underwent brittle deformation are known, with the former category dominating. Geological research on seismites has been pursued since the definition was first introduced by Seilacher (1969). Studies by Plaziat et al. (1990), Purser et al. (1993), Rodríguez-Pascua et al. (2000), Goffredo et al. (2002), Wheeler (2002), Moretti et al. (2002), Montenat et al. (2007), Van Loon (2009), Owen et al. (2011), Owen \& Moretti (2011) and Van
Loon \& Mazumder (2013) dealt with the formation conditions, principles, identification criteria, judgement standards, classification, and typical examples of seismites and their SSDS. In China, research by Qiao et al. (1994, 2001, 2006, 2013), Liang et al. (1994), Du \& Han (2000), Du et al. (2001, 2007), Qiao \& Li (2009), Van Loon \& Su (2013) and Van Loon (2014b) on the formation, classification, and identification of seismites have played a leading and driving role in seismite research.

Guo et al. (2002) were the first to use the term 'seismic volcanic rock' when investigating the Early Cambrian earthquakes in Luonan, China, for volcanic rocks affected by volcanism-induced earthquakes. Tian et al. (2007) identified seismic volcanic rocks in the Lower Cretaceous of the Yishu Fault Zone. From field profiling and laboratory analysis, 
we succeeded in distinguishing seismites and seismic volcanic rocks in the Shanwang and Yaoshan Formations of the Neogene Linqu Group in the Linqu area of Shandong Province for the first time. These rocks record palaeo-earthquakes that are responses to the intense tectonic extension and rifting of the Yishu Fault Zone and the faulted basins in its vicinity.

\section{Geological setting}

The Linqu area of Shandong Province lies west of the Yishu Fault Zone (Fig. 1). The $20-80 \mathrm{~km}$ wide, NNE-SSW striking Yishu Fault Zone, composed of four main faults, makes up the middle segment of the Tanlu Fault Zone. The Tanlu Fault Zone is a translithospheric deep and large fault system in eastern China that has frequently resulted in intense tectonic and seismic activity since the Neoproterozoic (Zhang et al., 1978; Qiao et al., 2001). Intense seismic processes in the Yishu Fault Zone occurred frequently during many geological intervals from the Neoproterozoic to the Cenozoic, giving rise to seismites and seismic volcanic rocks both inside this zone and in the syndepositional basins on its sides. Qiao et al. (1994) first discovered and examined Sinian seismites of a liquefied carbonate succession. Later, Chen et al. (2003), Tian et al. (2003, 2005, 2006, 2013), Yuan (2004), Yin \& Yang (2005), Lü et al. (2011), He et al. (2011, 2012) and Wang et al. (2013) studied seismites of different ages inside this fault zone and in the nearby basins.

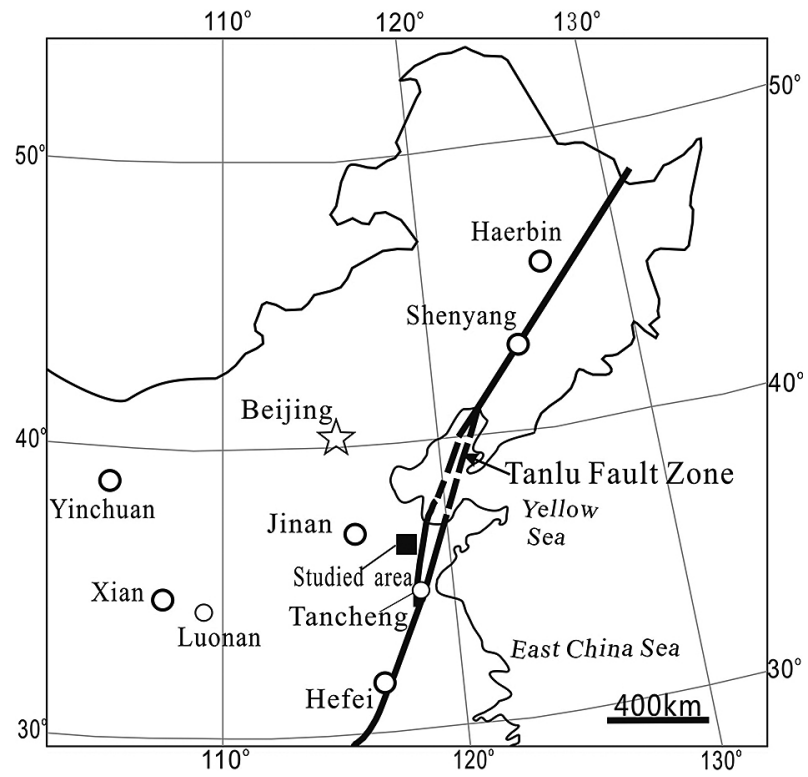

Fig. 1. Location of the studied area.
Two minor volcanic faulted basins, the Linqu and Shanwang Basins, are present in the study area (Fig. 2). The former lies near the county town of Linqu, and the latter in the Shanwang National Geopark, east of this town. The faulted basins are the result of intense Mesozoic-Cenozoic tectonic extension and rifting; the development of these basins was closely related in time with the nearby NE-SW and NW-SE trending faults in the Yishu Fault Zone (Wan, 1992, 1993; Zhang et al., 2004). In the areas where volcanic rocks are present, fault-bound central edifices (volcanic craters and volcanic cones) occur that are the products of fissure effusion and fault-related central-vent eruptions (Guo et al., 2007). The massive urban expansion and road construction in the county during recent years has exposed a large amount of bedrock in the Linqu Basin, creating favourable conditions for the present study.

The study area is located in the western part of Shandong Province. The basement of the basins consists of Early Cretaceous volcanic rocks, Mesoproterozoic adamellite masses and Cambrian carbonatite formations. The Cenozoic rocks in this basin include the Palaeogene Wutu Group, the Neogene Linqu Group, and Quaternary (Pleistocene and Holocene) deposits. The Wutu Group consists of fluvial and lacustrine clastic rocks, partly fine-grained mudstones. The Linqu Group is divided, from bottom to top, into the Niushan, Shanwang, and Yaoshan Formations (Zhang \& Liu, 1996; Song \& Wang, 2003). Figure 3 shows the thicknesses and lithological variations of the Linqu Group formations.

The Niushan Formation consists of basalts with alluvial clastic rocks at the base. Several basalts have K-Ar ages in the range 16.15-19.76 Ma, with an average of $18 \mathrm{Ma}$ (Zhang \& Liu, 1996), thus dating the formation as early Miocene.

The Shanwang Formation consists primarily of lacustrine sediments and is thicker in the East than in the West. Fluvial clastic rocks are present at the base and top of this formation. Laminated diatomites intercalated with clastic rocks containing phosphorite nodules form the mid-lower part. The upper part contains basalts intercalated with sandstones and mudstones (Zhang \& Liu, 1996). The Shanwang biotas typically occur in the laminated diatomites intercalated with clastic rocks. From the South 2nd Loop Road to Taojia Village, the diatomite and basalt become thinner, while the mudstones and sandstones become thicker. Sandy limestone and calcareous deposits (earthy chalk ore) are also present (Jing et al., 2004). In the Niushan area, this formation is at its thinnest and consists of mudstones and sandstones intercalated with diatomites. As the average K-Ar age of the basalt intercalations 
Fig. 2. Geological and location map of the Linqu area in Shandong Province, China. YFZ $=$ Yishu Fault Zone.

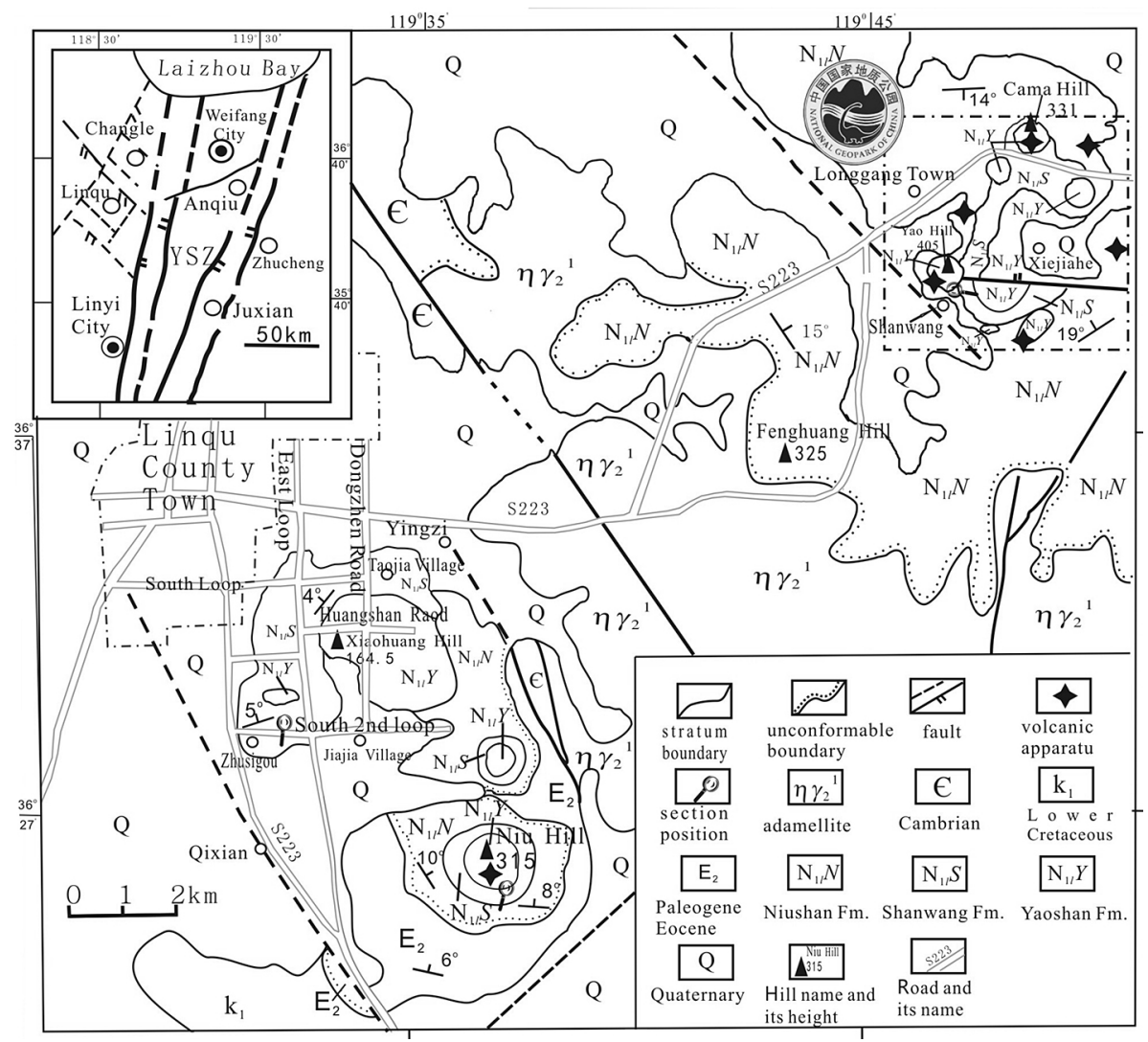

is $13 \mathrm{Ma}$ (Zhang \& Liu, 1996), the Shanwang Formation was formed in the Middle Miocene.

The Yaoshan Formation is principally composed of basalts, with conglomerates, thick tuffaceous sandstones intercalated with thin siltstones and mudstones at the base, and irregular silty fine sandstone intercalations in the centre. The formation thickens from the West to the East. The K-Ar age of the basalt is 5.94-11.40 Ma, with an average of 8.78 Ma (Chen \& Peng, 1985). This formation thus formed in the Late Miocene.

\section{Seismites}

The conditions under which the seismites under study developed, are consistent with the criteria for seismically triggered soft-sediment deformation structures (SSDS) (cf. Goffredo et al., 2002; Wheeler, 2002; Owen \& Moretti, 2011): (1) seismites are developed in sedimentary basins in tectonically active regions or strong seismic zones; (2) soft lacustrine sediments are susceptible to liquefaction-induced deformation and thixotropic deformation resulting from the seismic shock waves produced by strong earthquakes (see also Üner, 2014, this issue); (3) these SSDS occur over large distances in specific sedimentary levels; (4) steep slopes preferably do not exist in the basin and most SSDS are associated with syn-deformational faults. Therefore, they must be interpreted as synsedimentary earthquake-induced (= seismogenic) soft-sediment deformation structures; it should be kept in mind, however, that the various attempts to establish 'diagnostic' criteria for the recognition of seismites should be handled with utmost care (Moretti \& Van Loon, 2014). Further it is should be mentioned here that not all shock waves that may trigger the formation of SSDS are faulting-related: volcanic activity can also trigger the formation of SSDS. In the following, examples of both types in the study area are described and interpreted.

\subsection{Seismites with SSDS triggered by earthquakes}

Various types of earthquake-induced SSDS formed as a result of plastic deformation, liquefaction and/or fluidisation have been found in the study area (see also Van Loon \& Pisarska-Jamroży, 2014). These comprise (1) load, ball-and-pillow and flame structures, (2) pillow structures dominating specific beds, (3) slump folds, (4) boudinage structures, (5) syn-deformational faults, and (6) sedimentary dikes and veins. 


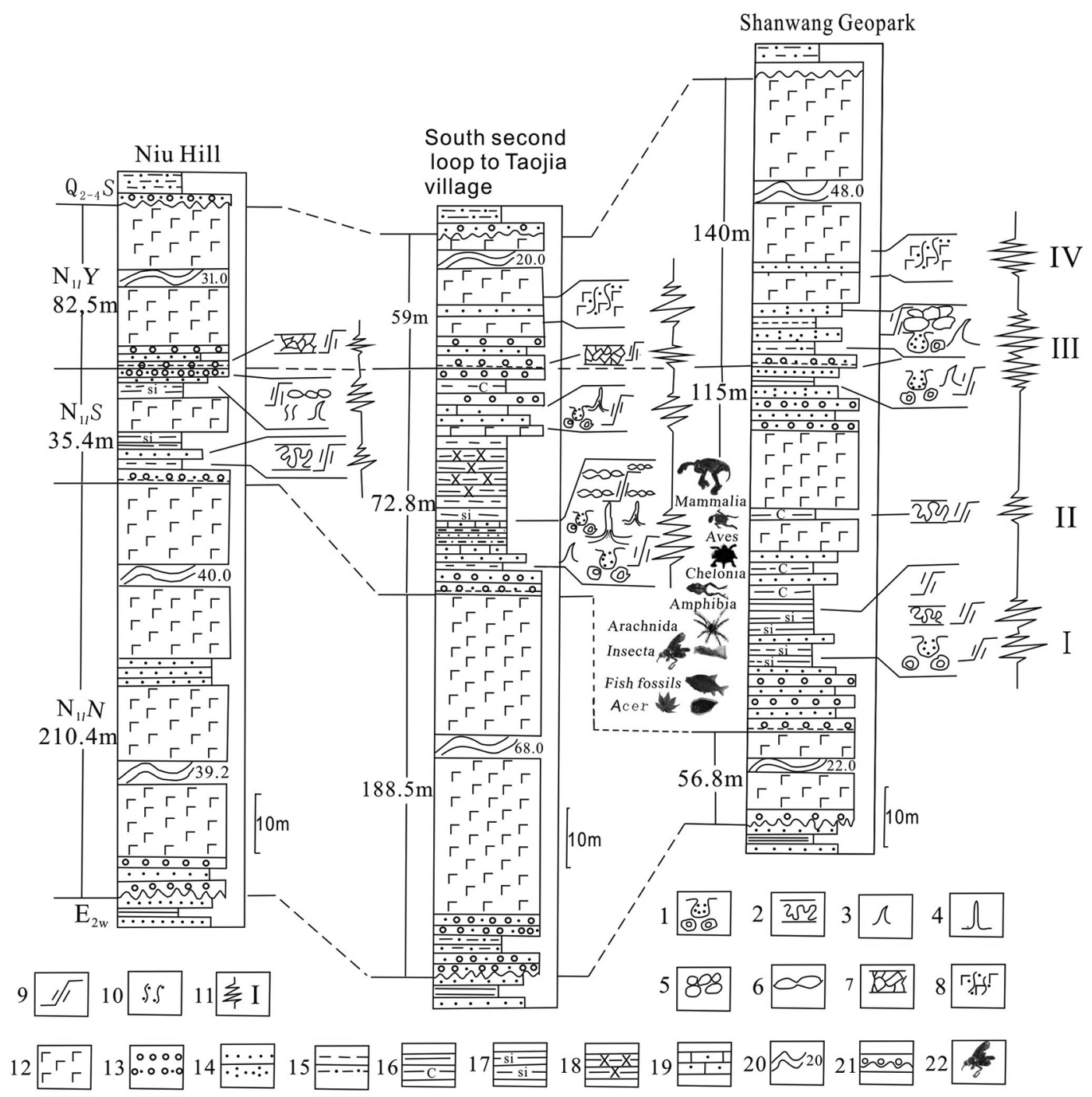

Fig. 3. Sedimentary logs with deformation structures induced by earthquakes from the Neogene Linqu Group $\left(\mathrm{N}_{11}\right)$ in the Linqu area of Shandong, China (for location, see Fig. 2).

Legend: 1: load and ball-and-pillow structures; 2: seismogenic (intra-layer) slump fold; 3: flame structure; 4: dike of liquefied sand;5: pillow bed; 6: boudinage structure; 7: brittle seismite; 8: seismic volcanic rock (basaltic shattered rocks and breccias) with sand veins; 9: syn-deformational fault (fault-graded); 10: liquefied-sand vein; 11: seismically active episode; 12: basalt; 13: conglomerate and sandy conglomerate; 14: sandstone and tuffaceous sandstone; 15: mudstone and sandy mudstone; 16: shale and carbonaceous shale; 17: laminated diatomite; 18: earthy chalk ore (calcareous deposit); 19: sandy limestone; 20: compressed basalt layer and its thickness (m); 21: unconformable contact; 22: characteristic fossils of the Shanwang biota (from the Shanwang Geopark Museum).

3.1.1. Load, ball-and-pillow, and flame structures 3.1.1.1. Description Load, ball-and-pillow, and flame structures (Figs 3, 4B,E, 5A,B) are present in the Shanwang and Linqu Basins and often make up associations of SSDS (Fig. 5E-2). In Figure 4B, the load cast on the right-hand side has been broken into fault blocks. The parent rocks of the load casts and ball-and-pillow structures are mostly sandstones, pebbly sandstones, and sandy conglomerates; these SSDS have sizes typically in the range of $10-80 \mathrm{~cm}$. Flame structures are composed of fine sandstone, siltstone, argillaceous siltstone and mudstone; they tend to have a wider lower part and a narrower upper part, and they commonly have a length of $5-50 \mathrm{~cm}$.

3.1.1.2. Interpretation Load structures are, as a rule, products of sediments that have a higher density than the sediments below them (e.g. sand on silt). Such reversed density gradients may, under the influence of seismic vibrations or gravity, result in sinking of the denser sediments into the lighter sediments, forming a bulb-like or synclinal structure, while the underlying lowdensity sediments intrude upwards between 

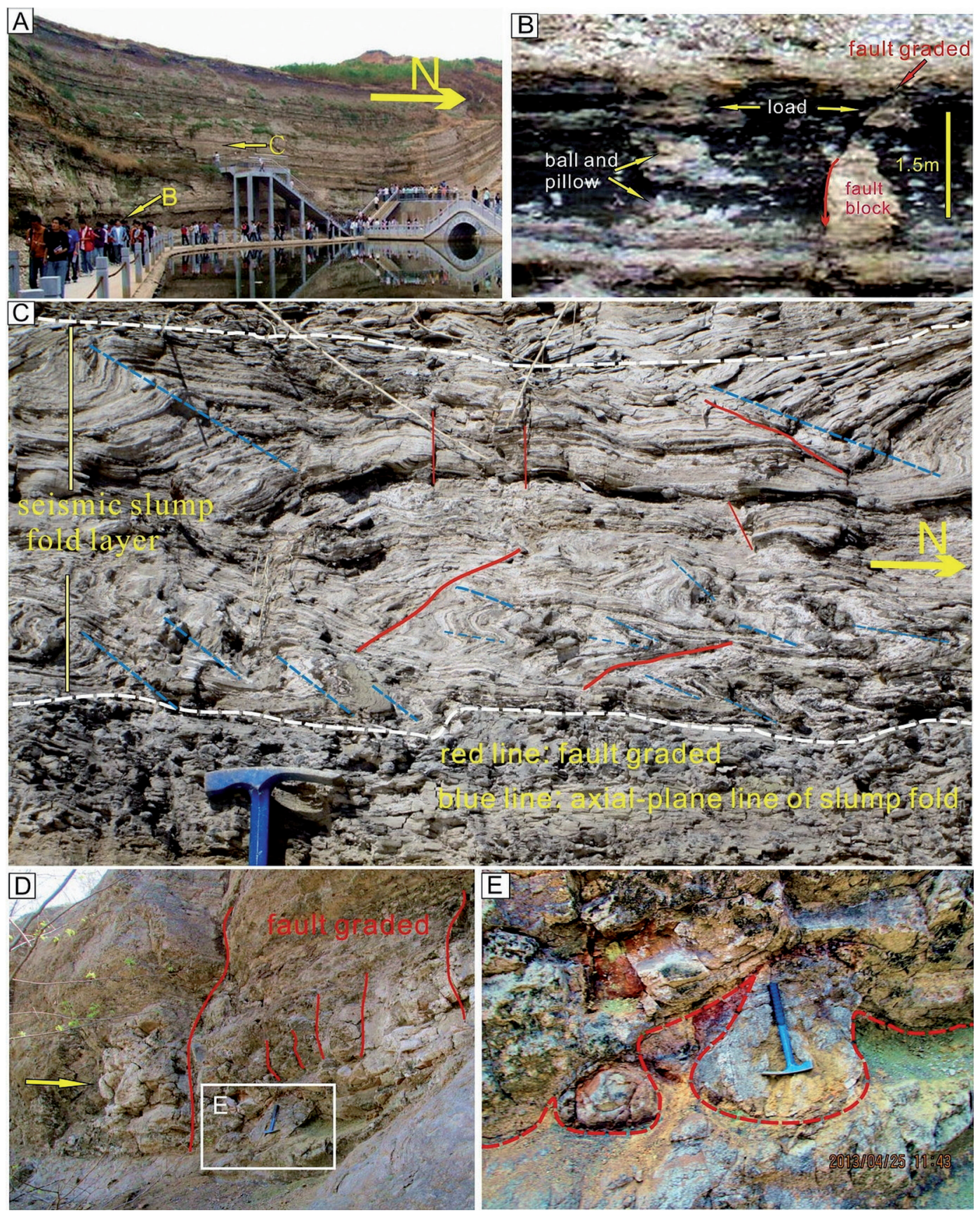

Fig. 4. Seismites with SSDS from the Shanwang and Yaoshan Formations in the Shanwang Basin, Linqu, Shandong. A: Exposed section of the lower part of the Shanwang Fm. in the Shanwang Geopark; B: Load and ball-and-pillow structures of sandstone associated with synsedimentary faults (fault graded); the surrounding rock is composed of dark sandy diatomite. The fault block on the right is a down-faulted load fragment. For location, see Figure 4A; C: Seismic slump fold in seismically-induced unconformable contact with underlying and overlying strata, and showing syn-deformational faults. The blue dashed lines show the axial planes of the slump folds. For location: See Figure 4A; D: Pillow beds (yellow arrow) with syn-deformational faults (fault-graded: red line) of tuffaceous sandstone at the base of the Yaoshan Fm. Location: eastern slope of Yaoshan; E: Load and flame structures of sandstone intercalated with siltstone. For location: see Figure 4D.

the bulbs in a liquefied or thixotropic state, thus forming flame structures between the load casts. The lower parts of the load casts, if subjected to vibration (for instance by seismic shock waves), may lose the contact with their parent layer, thus giving rise to balls or ellipsoids; these are called pseudonodules or, if both the originally upper and lower layers involved are sandy, ball-and-pillow 


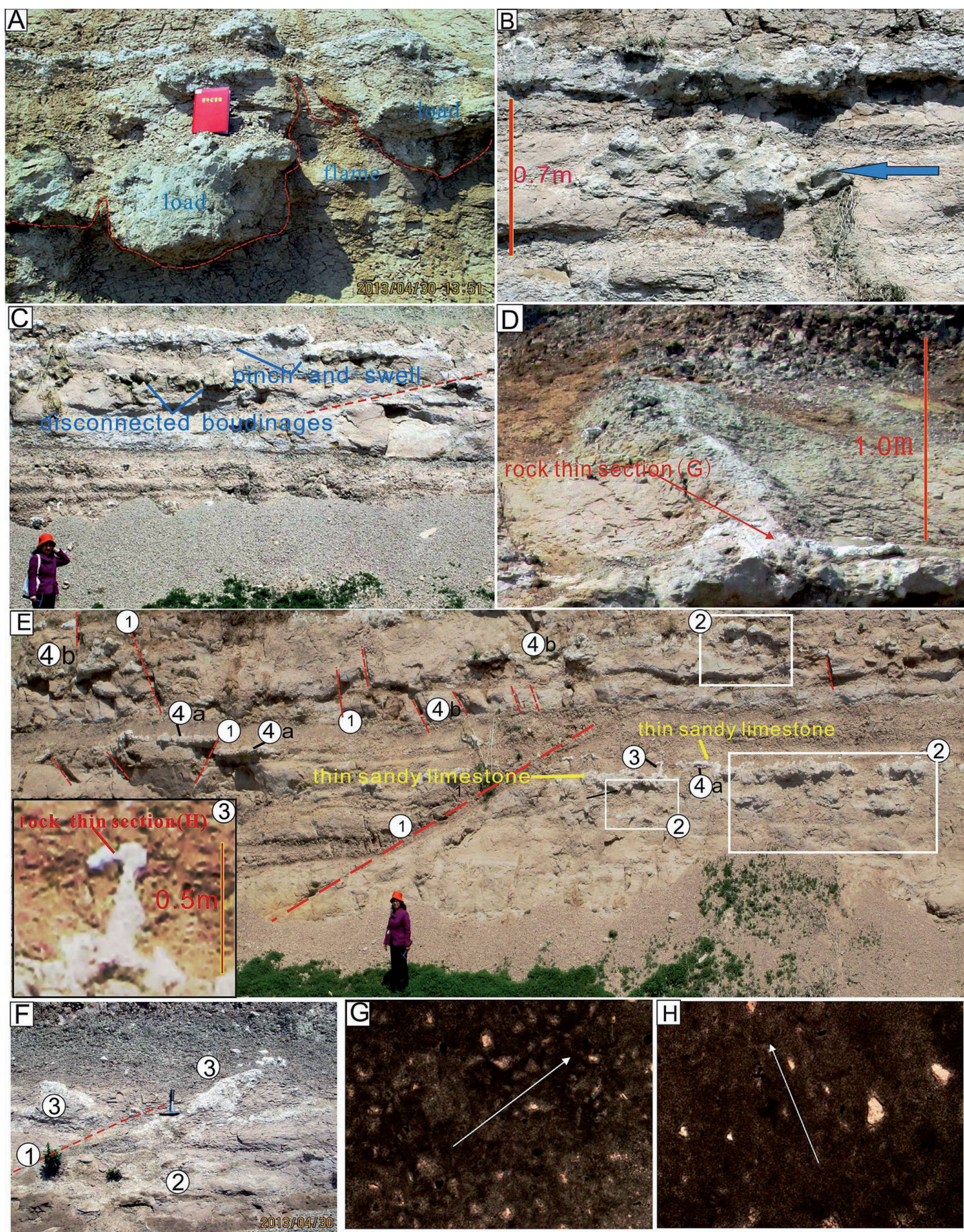

Fig. 5. Seismites with SSDS from the Shanwang Fm. in the Linqu Basin, Shandong. The geologist is $1.58 \mathrm{~m}$ tall.

A: Load and flame structures; B: Ball-and-pillow structures (arrow); C: Boudinage structures which include pinchand-swell and disconnected boudinages, and syn-deformational faults; D: Dike of liquefied sandy lime-mud (now limestone), from the base of which rock thin sections were studied (Fig. 4G); E: A selection of the deformation structures: syn-deformational fault; association of load, ball-and-pillow, and flame structures; dike of liquefied sandy mud (now limestone), from the top of which thin sections were studied (Fig. 4H); a pinch-and-swell \& b disconnected boudinage structures; F: syn-deformational fault; ball-and-pillow structure; lime-mud (now limestone) dike; G: Photomicrograph of a thin section from the basal part of the dike consisting of liquefied lime-mud in Figure 4D (plane-polarised light, $x 40)$, which consists of calcite (75-80\%), quartz (20-25\%) and limonite (1\%). In Figures 5G and $5 \mathrm{H}$, the arrows point to tips of angular sand grains along the long axis, displaying the flow direction of the sand grains; H: Photomicrograph of a thin section from the top part of the dike consisting of liquefied lime-mud in Fig. 4E (plane-polarised light, x40), which consists of calcite (90-95\%), quartz (5-10\%) and traces of limonite. 
structures (Moretti et al., 2002; Qiao \& Li, 2008, 2009; Tian et al., 2013).

\subsubsection{Pillow beds}

3.1.2.1. Description Pillow beds with thicknesses of 1.4-1.6 m occur only at the base of the Yaoshan Formation in the Shanwang Basin, where the sandstone thickness of the Yaoshan Formation is largest (Figs 3 \& 4D) in the Linqu area. The pillows consist of tuffs with dominantly sandstone-sized particles, but also with ejecta with longest axes of 20-50 cm and shortest axes of 15-25 cm. Most structures have a pillow-like or, in a few cases, a ball-like shape, and they occur roughly parallel to each other. The space between the pillows is filled with siltstone and mudstone. The pillow beds contain load structures of tuffaceous sandstone, and flame structures of siltstone and mudstone at the base (Fig. 4E); they show syn-deformational faults.

3.1.2.2. Interpretation The pillows are accumulations of dense load and ball-and-pillow structures after continuous deposition. The vast majority of the original load and ball-and-pillow structures have disappeared (Roep \& Everts, 1992; Qiao et al., 2009).

\subsubsection{Seismogenic slump folds}

3.1.3.1. Description At the edges of both basins in the study area, some intra-layer folds occur in the laminated diatomite of the Shanwang Formation, This is visible in a $40-80 \mathrm{~cm}$ thick synsedimentary fold layer) (Figs 3, 4C) associated with syn-deformational faults (red lines in Fig. 4C). The folds in the layer with many small overturned folds and recumbent folds do not affect the over- and underlying layers. Although the sizes and the dip angle of the axial planes of these folds differ, the dip directions of the axial planes are the same (i.e. NNE), which indicates that they were formed by SSW to NNE movement.

3.1.3.2. Interpretation The folds are typically slump folds (see also Perucca et al., 2014, this issue). They are associated with syn-deformational faults (Fig. 4) which implies that these soft-sediment folds are of seismic origin since syn-deformational faulting is (also called 'fault grading') is a seismogenic deformation structure, as detailed by Seilacher (1969). The characteristics of the folds are consistent with those of seismogenic slump folds or slump sheets induced by earthquakes in unconsolidated laminated sediments, as explained in numerous studies (e.g. Plaziat et al., 1990; Purser et al., 1993; Montenat, 2007; Van Loon, 2009; Owen et al., 2011; Su et al., 2013). The gentle character of the slope at the basin edge in the study area is due to slumping of soft diatomites under influence of seismic shocks in combination with gravity.

N-trending shear slip surface may have developed first at the base of a soft diatomite layer, after which slumping could take place. After an earthquake, a new diatomite layer accumulated on top of the slump folds, thus producing an uncomformable contact (a seismo-disconformity) (Liang et al., 1994).

\subsubsection{Boudinage structures}

3.1.4.1. Description Boudinage structures (Figs $3,5 \mathrm{C}, 5 \mathrm{E}-4)$ are present in the lower part of the Shanwang Formation in the Linqu Basin. They are mostly sandstone boudinages which occur as two types: pinch-and-swell structures (Fig. 5E-4-a) and disconnected boudinage structures (Fig. 5E-4-b).

The pinch-and-swell structures are 1.0-5.0 m long. The disconnected boudinages are strip-shaped and lenticular with a length of 0.2-1.0 m; they occur in specific levels. The over-and underlying rocks of the layer with the boudinage structure consist of sandy mudstone and fine argillaceous siltstone. It is obvious that the original sediments were finegrained (mud and mud-containing siltstone) intercalated between coarse-grained sedimentary deposits (sand).

3.1.4.2. Remarks From rock and soil mechanics as well as from simulation experiments ( $\mathrm{Wu}$ et al., 2005), it is known that fine-grained sedimentary deposits are more plastic, whereas coarse-grained sediments are relatively rigid. Their mechanical properties differ significantly (e.g., Chen et al., 2013). The boudinage structures developed because, under vertical non-uniform extrusion and horizontal extensional seismic forces, the finegrained sediments flowed plastically and produced shear stresses on top of the sand layer, which then pinched and swelled non-uniformly but remained unbroken, thus forming pinch-and-swell structures. When a pinch-and-swell structure was broken, a disconnected boudinage structure was created. Sand layers with a lower moisture content and a higher rigidity could be broken by shorter syndeformational faults and thus become mutually disconnected more or less rectangular boudinage structures.

\subsubsection{Syn-deformational faults}

3.1.5.1. Description Syn-deformational faults tend to be associated with a wide range of other seismogenic deformation structures (Figs 3, 4B-D, $5 \mathrm{C}, \mathrm{E})$; they are found in the Shanwang Formation of the Linqu and Shanwang Basins. Being characterised by small sizes and a widespread distribution, these faults are mostly $0.3-2.5 \mathrm{~m}$ long, with a maximum 


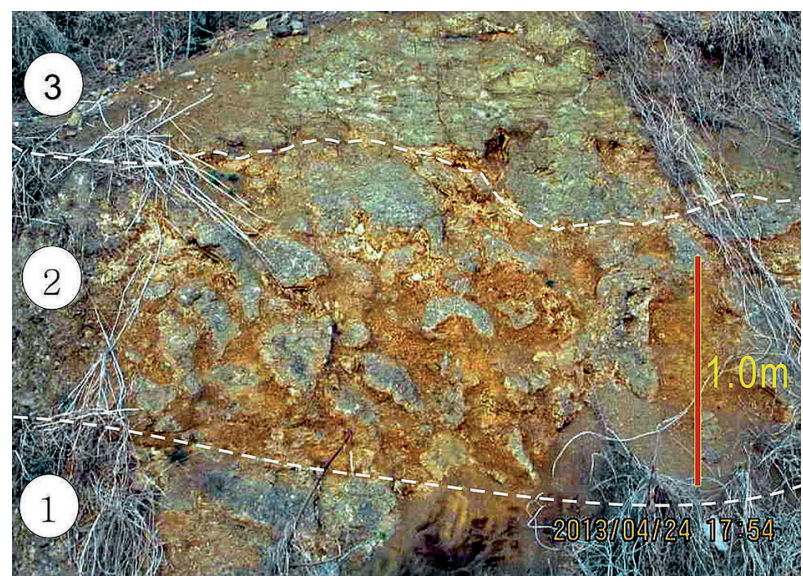

Fig. 6. Brittle seismites at the bottom of the Yaoshan Fm. in Linqu.

1: Lower part of a conglomerate; this lower part was already in a consolidated state when an earthquake took place, but due to its consolidated state it was hardly affected by the earthquake; 2: Middle part of a conglomerate that was in a semi-consolidated state when it was affected by an earthquake. The seismic shock resulted in fragmentation of the conglomerate, thus forming a seismogenic breccia; 3: After the earthquake, a sandstone layer deposited on top of the seismogenic breccia via a sedimentary unconformity. The rocks have undergone intense weathering during the Quaternary.

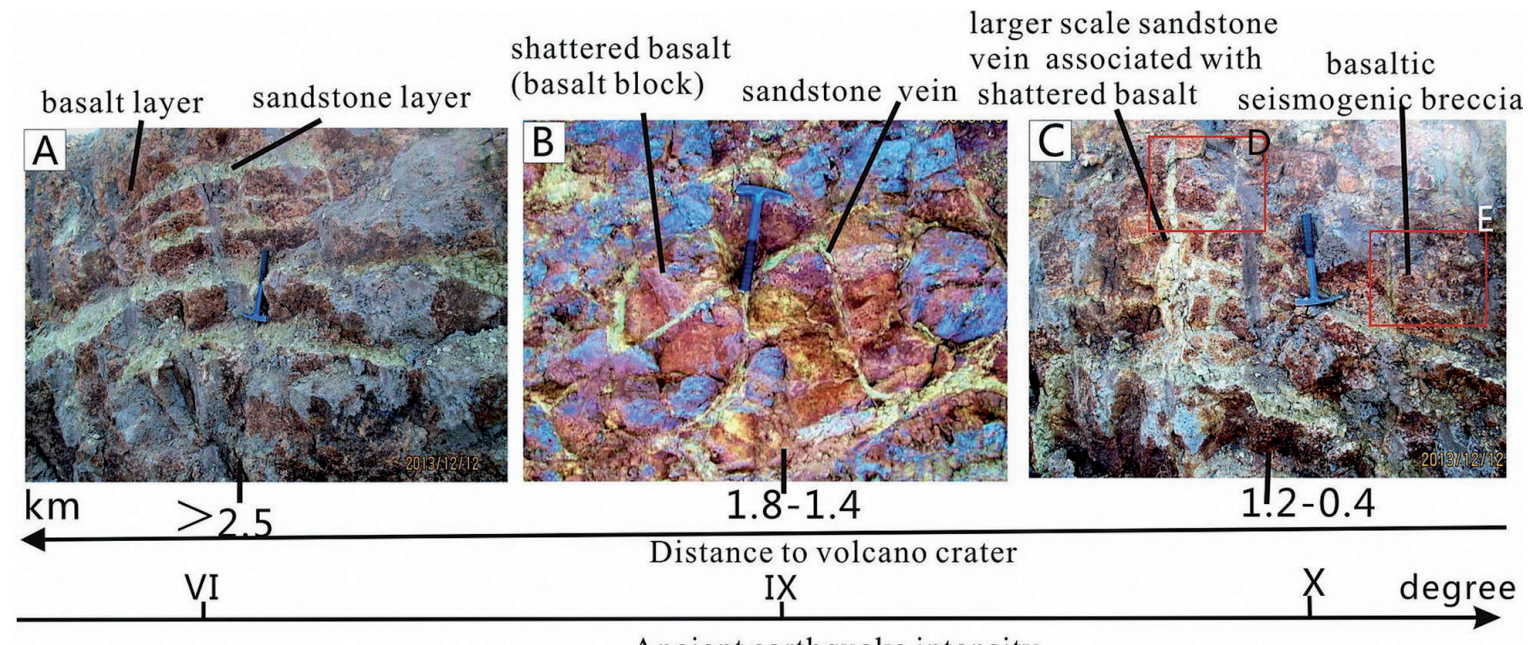

Ancient earthquake intensity
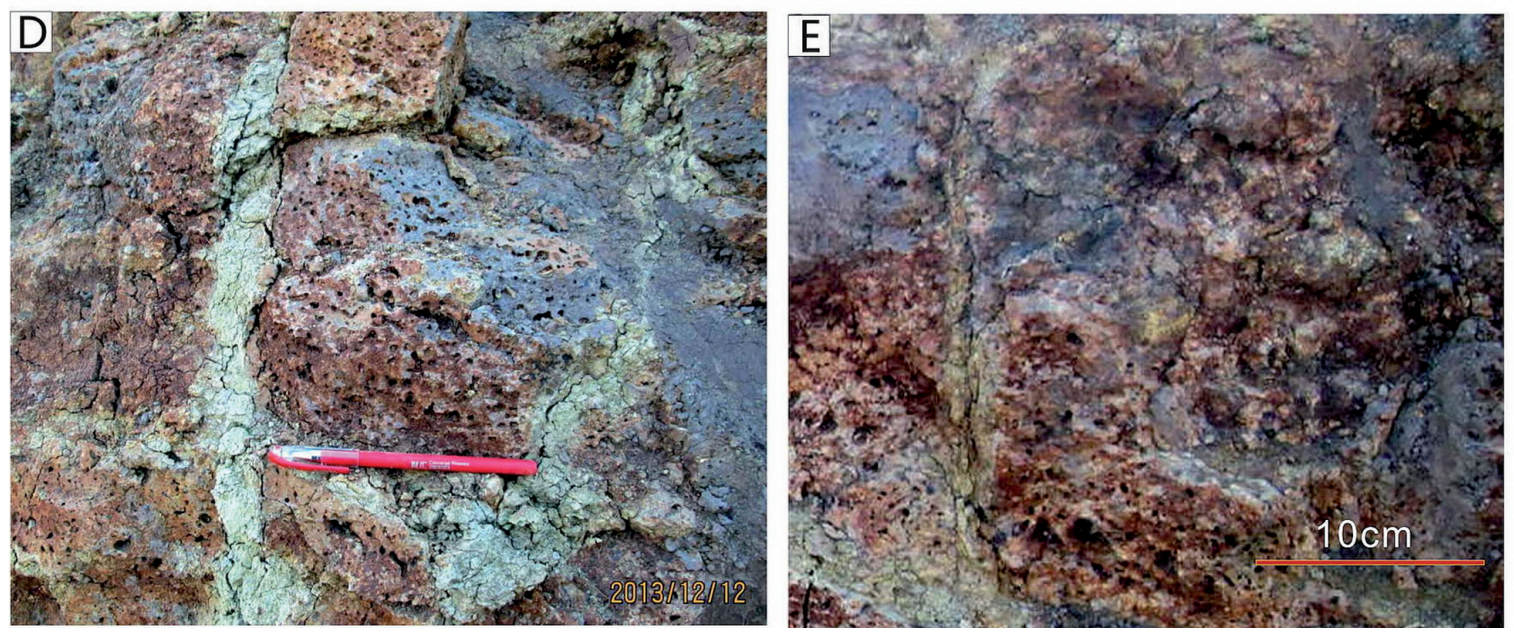

Fig. 7. Features, types and interpreted earthquake intensity of seismic volcanic rocks associated with liquefied-sand veins in the Yaoshan Fm. of the Linqu Basin, Shandong. In Figures 7A, B and C, the distances to the nearest volcano are indicated and the interpreted earthquake intensity (as reflected by the degree of seismogenic deformation) is provided.

A: Medium- to thick-bedded basalt layers intercalated between buff layers of seismically liquefied sand (now sandstone) with only a few liquefied-sand veins; the basalt layers are in essence still intact; B: Shattered basalt with a network of small intruded veins of seismically liquefied sand (now sandstone); C: Shattered basalts, basaltic seismogenic breccias and larger-scale veins of seismically liquefied sand; D: Close-up of basalt with a clear vesicular structure, seismically shattered basalt blocks, and still wider veins of seismically liquefied sand; E: Close-up of basaltic seismogenic breccias. 
length of approx. $5 \mathrm{~m}$ (Fig. 5E), and their faultthrows are quite limited (only $0.5-50 \mathrm{~cm}$ ).

3.1.5.2. Remarks Syn-deformational faults are intralayer faults resulting from the adjustment of disturbed sediments immediately following an earthquake (Qiao et al., 1994). They are commonly associated with seismites, as first recognised by Seilacher (1969), who mentioned beds with this feature 'fault-graded beds', a term that has become obsolete now. Earthquake-triggered SSDS are always accompanied by syn-deformational faults according to some workers (Wheeler, 2002; Du et al., 2008; Tian et al., 2011).

\subsubsection{Dikes and veins}

3.1.6.1. Description Dikes formed by intruding liquefied sandy lime-mud (limestone) dikes (Figs 5D-F) are present in the Shanwang Formation of the Linqu Basin and are connected in their lower parts with a lime-mud layer that must be considered as their source rock. They are wider at the bottom and intrude upwards into sandy mudstone. The lower parts of the dikes are $20-30 \mathrm{~cm}$ wide and their entire length is $60-90 \mathrm{~cm}$. The material inside the dikes consist of calcite (8-12 $\mu \mathrm{m}$ in size) and quartz (10-30 $\mu \mathrm{m})$, with large amounts of quartz sand in the lower part (Figs 5G-H). The tips of angular sand grains point to the long axis, indicating the flow direction of the sand grains.

Inside the basalt and fine-sandstone intercalations in the middle part of the Yaoshan Formation of the Linqu Basin (Fig. 7A), buff, liquefied, finesand veins (Fig. 7B-E) fill the fissures in the seismic volcanic rocks. The veins generally are $1-6 \mathrm{~cm}$ wide and $10-40 \mathrm{~cm}$ long.

3.1.6.2. Remarks The conditions and mechanisms underlying the formation of liquefied fine sand veins and seismic volcanic rocks are discussed in Section 4 (see also He et al., 2014, this issue). Dikes and veins consisting of material that intruded in a liquefied or fluidised state are water-escape structures on various scales resulting from the water-saturated sediments that became affected by seismic vibration, which allowed water to escape along zones of weakness (commonly cracks or micro-fissures) in the adjacent rock (see also Valente et al., 2014, this issue). Such structures are present in many seismic-event strata in the Yishu Fault Zone and its vicinity (Qiao et al., 1994; Tian et al., 2003, 2005; Chen et al., 2003; Yuan, 2004; Yin \& Yang, 2005; He et al., 2011; Tian et al., 2013).

\subsection{Brittle seismites}

A 1.1-1.3 m-thick intralayer breccia (Fig. 6, layer 2) occurs at the base of Yaoshan Formation; it is exposed in the Xiaohuang Hill - Niu Hill district of the Linqu Basin (Fig. 2). The brecciation points at brittle deformation (see also Sarkar et al., 2014, this issue).

\subsubsection{Description}

The left half of the layer described here (Fig. 6, layer 2) consists mainly of shattered rock fragments containing clasts of over $10 \mathrm{~cm}$ in size; the clasts have angles that point at cracks. The right half of the layer consists mainly of breccias with small clasts $(<5 \mathrm{~cm})$, the majority of which are without any signs of cracks. As a result of intense weathering during the Quaternary, some clasts with sharp angles in the breccias have become split into finer fragments. The brittle deformed bed shows a gradual transition into the underlying conglomerate bed but the contact is a seismic disconformity (Liang et al., 1994). The undeformed overlying sandstone results from post-earthquake deposition.

\subsubsection{Remarks}

The genesis of the brittle deformed layer is explained in Fig. 6 1-3. The original rock was a semi-consolidated conglomerate which, under the influence of seismic shocks, had its original bedding destroyed: it was fractured to form shattered rock fragments with clasts indicating fracturing. Some of the conglomerate was broken into fragments without forming seismogenic breccias; they underwent minor slip displacement under the influence of gravity after they had originated. The cracked nature is diagnostic for shattered rocks and seismogenic breccias (Qiao et al., 2006; Tian et al., 2006; Su \& Sun, 2011). In Middle Ordovician formations in the vicinity of the studied area that were affected by earthquakes (Tian et al., 2006), some brittle seismites are also present.

\section{Seismic volcanic rocks}

\subsection{Description}

In the Xiaohuang Hill - Niu Hill district of the Linqu Basin as well as in the Yao Hill of the Shanwang Basin (Fig. 2), seismic volcanic rocks associated with liquefied-sand veins occur in medium to thick basalts with intercalations of silty fine sandstones over their total thickness of 5.5-6.0 $\mathrm{m}$ in the lower part of the Yaoshan Formation (Figs 3 and 7). 
The present contribution focuses, however, on the seismic volcanic rocks of the Linqu Basin, which include shattered basalts and basaltic seismogenic breccias (Fig. 7B-E). Shattered basalts are composed of cracked angular basalt clasts (of 20-40 cm large), far away from the volcanic crater of Niu Hill. Fissures among the basalt blocks are filled by liquefied-sand veins. Basaltic seismogenic breccias occur all around the crater of Niu Hill; they consist of angular and sub-angular basaltic fragments $(1-8 \mathrm{~cm})$, without cracks and with rare sand veins.

\subsection{Interpretation and remarks}

Intense earthquakes caused the underwater basalt to break and become fractured, partly forming a basaltic shatter breccia. At the same time, liquefied silty fine sand intruded along seismically-induced fissures between shattered basalt fragments, giving rise to reticular liquefied-sand veins (Figs 7B, C). The seismogenic phenomena shown in Figure 7A-C are $2.5 \mathrm{~km}, 1.4-1.8 \mathrm{~km}$, and $0.4-1.2 \mathrm{~km}$, respectively, away from the crater of Niu Hill. The smaller the distance is to the crater of Niu Hill, the more shattered the seismic volcanic rocks are and the wider the veins are, indicating a higher seismic intensity. This suggests that the crater of Niu Hill was the epicentre of the earthquake(s) at the time and that the hypocentre was situated right under the crater. These seismic volcanic rocks and liquefied-sand veins are records of intense volcanic earthquake events accompanying eruptions through the central vent.

\section{Dating, type and intensity of the earthquakes}

\subsection{Dating and type of the earthquakes}

The duration of a seismically active period can be over many millions of years (Qiao et al., 2006). The layers containing relatively numerous SSDS can record such a palaeo-earthquake episode. Such an episode will commonly include many palaeo-earthquake events (Qiao et al., 2006). Each of the associations of seismogenic SSDS shown in Figure 3 actually records a palaeo-earthquake episode. As the Middle Miocene palaeo-earthquake record of Linqu (seismites and seismic volcanic rocks) starts in the lower part of the Shanwang Formation and ends in the lower part of the Yaoshan Formation, it represents a geological history of seismic activity of about 4 Ma (14-10 Ma). All seismogenic SSDS identified herein are records of the same palaeo-earthquake stage. This stage of palaeo-earthquake activity of the Linqu Group included four palaeo-earthquake episodes, although only three episodes are recorded in the Niushan area of Linqu on the margin of the basin. These three episodes are attributed to ongoing tectonics or frequent tectonics.

As no record of syn-depositional seismics has been found so far inside the Yishu Fault Zone, the SSDS must have resulted from activity of the boundary faults in the Linqu and Shanwang Basins. The fourth seismic episode should be attributed to volcanics: seismic volcanic rocks are produced by volcanism-induced earthquakes. Based on the isotopic age values of basalt intercalations (Chen \& Peng, 1985; Zhang \& Liu, 1996; Guo et al., 2007) and stratigraphic levels with seismogenic SSDS, the above authors calculated that the first tectonic seismic episode took place after the Niushanian volcanic event at around $14 \mathrm{Ma}$; the second took place at around $13 \mathrm{Ma}$, and was accompanied by minor Shanwangian volcanic eruptions; the third occurred before the Yaoshanian volcanic event of around 12 $\mathrm{Ma}$; and the volcanic seismic episode dates back to the beginning of the Yaoshanian volcanic eruption at around $10 \mathrm{Ma}$.

\subsection{Palaeo-earthquake intensity}

The earthquakes recorded by load and ball-andpillow structures had a magnitude of at least Ms $>5$ on the Richter scale (Qiao \& Li, 2008). According to Rodríguez-Pascua et al. (2000), liquefied-sand veins represent also a magnitude of $\mathrm{Ms}>5$. The seismic intensity, as measured by the Chinese standard for seismic intensity (GB/T17742-2008), is $\geq$ VI. The seismogenic breccia (Fig. 7) is the same as the fractured gravels that indicate $\mathrm{Ms}=8$, as described by Rodriguez-Pascua et al. (2000). Hence, we assume that its intensity was XI. According to the Chinese seismic intensity scale, the seismic intensity represented by hard-rock dislocation is IX, and the intensities reflected by fracturing and shattering of basalt layers are IX and $X$, respectively. The epicentral intensity $\left(I_{0}\right)$ can be re-calculated to the Richter scale (Ms) following the formula Ms $=0.66 I_{o}+0.98$ (Shi, 2007). This implies that the seismic magnitude recorded by the basaltic shatter breccia is calculated to be Ms =7.58; that the magnitude recorded by the longer syn-depositional seismogenic faults (Figs 4B and $5 \mathrm{E}$ ) is $\mathrm{Ms}=7$. Therefore, the seismic magnitude reflected by the seismite in the Shanwang Formation should be Ms > 5-7 with an earthquake intensity of $\geq$ VI-IX. The palaeo-earthquake magnitude 
recorded by the breccia seismite and the seismic volcanic rocks in the Yaoshan Formation indicates a magnitude of 7.58-8, with intensities of IX-XI.

\section{Tectonic significance}

According to Wan (1992), tectonic stresses in Shandong Province were compressional in S-N direction and stretching nearly E-W during the Neogene Himalaya tectonic cycle stage. Owing to extensional activities of the Yishu Fault Zone and nearby faults, intrusion and volcanic eruptions of basaltic magma derived from the mantle occurred along extensional faults almost at the same time, which resulted in the Linqu Group which mainly consists of basalts. During the more quiet phases between volcanic eruptions, sediments with diatomites and sands were deposited in lacustrine basins. The seismites under study here were formed when later volcanism- or fault-triggered earthquakes affected these still unconsolidated sediments in the volcanic basins.

The seismic volcanic rocks dealt with in the present contribution record the volcanic eruption of about $10 \mathrm{Ma}$. Because of the master/slave relationship between the Yishu Fault Zone and its neighbouring basins (Wan, 1993; Zhang et al., 2004; Tian et al., 2007), the seismic events recorded by the various above seismogenic rocks and the volcanic eruptions are all responses to the tectonic extension and basin rifting in the area, and even to the activity of the Yishu Fault Zone in the Himalaya tectonic cycle.

\section{Conclusions}

In the Middle Miocene (14-10 Ma), rifting of the Linqu and Shanwang volcanic faulted basins in Linqu, Shandong Province induced, as a result of the tectonic extension of the Yishu Fault Zone and the surrounding area, a series of earthquakes with Richter magnitudes of 5.0-8.0 ( $\left.\mathrm{M}_{\mathrm{s}} 5-8\right)$. The soft sediments in the lake basin became deformed by the earthquakes, thus becoming seismites with various types of SSDS, including load structures, ball-and-pillow structures, flame structures, pillow beds, boudinage structures, seismogenic slumps, syn-deformational faults (fault grading), liquefied-sand veins, and liquefied-sandy/limy dikes, which are preserved in the Shanwang Formation of the Linqu Group.

Semi-consolidated conglomerates became, under the influence of the seismic shocks, brecciated, forming brittle seismites; these occur at the base of the Yaoshan Formation. The intense earthquakes induced by volcanic eruptions shattered and brecciated the basalt layers in the succession of alternating basalt and sand layers at the base of the Yaoshan Formation, thus forming so-called seismic volcanic rocks (shatter basalts and basaltic seismogenic breccias), which are associated with liquefied-sand veins formed by the sand that became liquefied due to earthquakes and that intruded the cracks in the basalt.

\section{Acknowledgements}

This study was supported by the National Natural Science Foundation of China (Grant No. 41272066) and the Program for Changjiang Scholars \& Innovative Research Team at the University of China (IRT13075). We wish to thank Prof. Qiao, He, and Su of the Chinese Academy of Geological Sciences for their helpful discussions and review on an earlier version of the manuscript.

\section{References}

Chen, D.G. \& Peng, Z.C., 1985. K-Ar ages and Pb-Sr isotopic characteristics of Cenozoic volcanic rocks in Shandong, China. Geochimica 4, 293-303 (in Chinese with English abstract).

Chen, J. \& Lee, H.S., 2013. Soft-sediment deformation structures in Cambrian siliciclastic and carbonate storm deposits (Shandong Province, China): Differential liquefaction and fluidization triggered by stormwave loading. Sedimentary Geology 288, 81-94.

Chen, S.Y., Yuan W.F. \& Yan, J.H., 2003. Discovery and significance of earthquake event deposits of Early Tertiary in the Jiyang depression. Chinese Journal of Geology 38, 377-384 (in Chinese with English abstract).

Du, Y.S. \& Han, X., 2000. Seismo-deposition and seismites. Advance in Earth Sciences 15, 389-394 (in Chinese with English abstract).

Du, Y.S., Zhang, C.H., Han, X., Gu, S.Z. \& Lin, W.J., 2001. Earthquake event deposits in Mesoproterozoic Kunyang Group in central Yunnan and its geological implications. Science China (D: Earth Sciences) 31, 284-290

Du, Y.S., Shi, G., Gong, Y.M. \& Xu, Y.J., 2007. Permian soft-sediment deformation structures related to earthquakes in the Southern Sydney Basin, eastern Australia. Acta Geologica Sinica 81, 511-518 (in Chinese with English abstract).

Goffredo, M., Laura, C., Marco, B. \& Giacomo, C, 2002. Indicators of paleoseismicity in the lower to middle Miocene Guadagnolo Formation, central Apennines, Italy. Geological Society of America Special Paper 359, 87-98.

Guo, L.Y., Gan, Z.M., Zhang, G.W. \& Du, Y.S., 2002. The seismic stratigraphic analysis of Taowan conglomerate in Luonan, Shaanxi. Acta Scientiarum Naturalium Universitatis Pekinensis 38, 497-503. 
Guo, Z.F., Liu, J.Q. \& Chen, X.Y., 2007. Effect of Miocene basaltic volcanism in Shanwang (Shandong Province, China) on environmental changes. Science China (D: Earth Sciences) 50, 1823-1827 (in Chinese).

He, B.Z., Qiao, X.F., Tian, H.S., Chen, S.Q. \& Zhang, Y.X., 2011. Paleo-seismic event and the giant dinosaur fossil burial of Later Cretaceous, Zhucheng, Shandong province, China. Journal of Palaeogeography 13, 615-626 (in Chinese with English abstract).

He, B.Z, Qiao, X.F. Tian, H.S. \& Zhang, Y.X., 2012. Paleoseismic events of Early Cretaceous and dinosaur migration in Zhucheng of Shandong province, China. Acta Geologica Sinica 86, 1320-1330 (in Chinese with English abstract).

He, B., Qiao, X., Jiao, C., Xu, Z., Cai, Z., Guo, X., Zhang, Y. \& Zhang, M., 2014. Paleo-earthquake events in the late Early Palaeozoic of the central Tarim Basin: evidence from deep drilling cores. Geologos 20, 105-123.

Jing, X.D., Zhang, C., Ma, J.C. \& Wang, F.H, 2004. Geological characteristics of Cretaceous deposit in Taojiazhuang village of Linqu County in Shandong. Shandong Land and Resources, 20, 41-44 (in Chinese with English abstract).

Liang, D.Y., Nie, Z.T. \& Song, Z.M., 1994. A restudy on seismites and seismodisconformity - taking the western Sichuan and western Yunnan as an example. Earth Science 19, 845-850 (in Chinese with English abstract).

Lü, H.B., Wang, J. \& Zhang, H.C., 2011. Discovery of Late Mesozoic slump beds in Lingshan island, Shandong, and a pilot research on the regional tectonics. Acta Geologica Sinica 85,938-946 (in Chinese with English abstract).

Moretti, M., \& Van Loon, A.J., 2014. Restrictions to the application of 'diagnostic' criteria for recognizing ancient seismites. Journal of Palaeogeography 3, 13-24.

Moretti, M., Pieri, P. \& Tropeano, M., 2002. Late Pleistocene soft-sediment deformation structure interpreted as seismites in paralic deposits in the city of Bari (Apulian foreland southern Italy). [In:] F.R. Ettensohn, N. Rast \& C.E. Brett (Eds): Ancient seismites. Geological Society of America, Special paper 359, 75-85.

Montenat, C., Barrier, P., Ott d'Estevou, P. \& Hibsch, C., 2007. Seismites: an attempt at critical analysis and classification. Sedimentary Geology 196, 5-30.

Owen, G., Moretti, M. \& Alfaro, P. (Eds), 2011. Recognising triggers for soft-sediment deformation: Current understanding and future directions. Sedimentary Geology 235 (3/4), 133-342.

Owen, G. \& Moretti, M., 2011. Identifying triggers for liquefaction-induced soft-sediment deformation in sands. Sedimentary Geology 235, 141-147.

Perucca, L.P., Godoy, E. \& Pantano, A., 2014. Late Pleistocene-Holocene earthquake-induced slumps and soft-sediment deformation structures in the Acequion River valley, Central Precordillera, Argentina. Geologos 20, 147-156.

Plaziat, J.C., Purser, B.H. \& Philobbos, E., 1990. Seismites deformation structures (seismite) in the syn-rift sediments of the NW Red Sea (Egypt). Bulletin de la Société Géologique de France 8, 419-434.
Purser, B.H., Plaziat, J.C. \& Philobbos, E.R., 1993. Stratiform breccias and associated deformation structures recording Neogene earthquake in syn-rift sediments of the Egyptian Red Sea coast. Geological Society of Egypt, Special Publication 1, 189-204.

Qiao, X.F., Song, T.R., Gao, L.Z., Peng, Y., Li, H.B., Gao, M.I, Song, B. \& Zhang, Q.D., 1994. Seismic sequence in carbonate rocks by vibrational liquefaction. Acta Geologica Sinica (English edition) 68, 16-29.

Qiao, X.F., Gao, L.Z. \& Peng, Y., 2001. The Neoproterozoic in the paleo-Tancheng-Lujiang Fault Zone - catastrophe sequences biostratigraphy. Geological Publishing House (Beijing), 122 pp. (in Chinese).

Qiao, X.F. \& Guo, X.P., 2013. Early Jurassic soft-sediment deformation interpreted as seismites in the Wuqia pull-apart basin and the strike-slip Talas-Ferghana fault, Xinjiang, China. Acta Geologica Sinica (English edition) 87, 730-737.

Qiao, X.F., Song, T.R., Gao, L.Z., Li, H.B, Peng, Y., Zhang, C.H. \& Zhang, Y.X., 2006. Seismic records in strata. Geological Publishing House (Beijing), 263 pp. (in Chinese).

Qiao, X.F. \& Li, H.B., 2008. Pillow, ball-and-pillow structures: paleo-seismic records within strata. Geological Reviews 54, 721-730 (in Chinese with English abstract).

Qiao, X.F. \& Li, H.B., 2009. Effect of earthquake and ancient earthquake on sediments. Journal of Palaeogeography 11, 593-610 (in Chinese with English abstract).

Rodríguez-Pascua, M.A., Calvob, J.P., Vicentea, G.D. \& Gomez-Gras, D., 2000. Soft-sediment deformation structures interpreted as seismites in lacustrine sediments of the Prebetic Zone, SE Spain, and their potential use as indicators of earthquake magnitudes during the Late Miocene. Sedimentary Geology 135, 117-135.

Roep, T.B. \& Everts, A.J., 1992. Pillow-beds: A new type of seismites? An example from an Oligocene turbididite fan complex, Alicante, Spain. Sedimentology 39, 711-724.

Sarkar, S., Choudhuri, A., Banerjee, S., Van Loon, A.J. \& Bose, P.K., 2014. Seismic and non-seismic soft-sediment deformation structures in the Proterozoic Bhander Limestone, central India. Geologos 20, 89-103.

Seilacher, A., 1969. Fault-graded beds interpreted as seismites. Sedimentology 13, 155-159.

Shi, W., 2007. Engineering geology. Science Press (Beijing), 300 pp. (in Chinese).

Song, M.C. \& Wang, P.C., 2003. Regional geology of Shandong Province. Map Press of Shandong Province (Jinan), 970 pp. (in Chinese).

Su, D.C. \& Sun, A.P., 2011.Soft-sediment deformation and occurrence frequency of palaeoearthquake in the Mesoproterozoic Wumishan Formation, Yongding River Valley, Beijing. Journal of Palaeogeography 13, 591-614 (in Chinese with English abstract).

Su, D.C., Sun, A.P., Zheng, G.S., Lü, J.B. \& Guo, R.T., 2013. A preliminary research on the slump structures in Cambrian System in the Western Hills of Beijing. Acta Geologica Sinica 87, 1167-1075.

Tian, H.S., Wan, Z.J. \& Wang, H.L., 2003. Discovery and preliminary study on seismites of the Cambrian Man- 
tou Formation in the central Shandong area. Geological Review 49, 123-131 (in Chinese with English abstract).

Tian H.S., Wang, J.G, Lü, M.Y \& Wang, L.F., 2005. Seismic records in Paleogene alluvial layers in Anqiu, Shandong. Acta Sedimentologica Sinica 23, 75-81 (in Chinese with English abstract).

Tian, H.S., Zhang, Z.Q., Zhang, B.H, Du, S.X., Guo, G.J. \& Lü, M.Y., 2006. Records of paleoseismic events in the red-silk stone bed in Linqu, Shandong. Geology in China 33, 1137-1143 (in Chinese with English abstract).

Tian, H.S., Li, H.K., Zhang, Z.Q., Wang, J.G. \& Guo, G.J., 2007. New recognition of seismogenic rocks in the Yishu fault zone and its periphery. Acta Geoscientica Sinica 28, 496-506 (in Chinese with English abstract).

Tian, H.S., Zhang, Z.Q., Zhang, B.H., Zhu, J.W., Sang, Z.X. \& Li, H.K., 2013.Tectonic taphrogenesis and paleoseismic records from the Yishu Fault Zone in the initial stage of the Caledonian movement. Acta Geologica Sinica (English edition) 87, 936-947.

Üner, S., 2014. Seismogenic structures in Quaternary lacustrine deposits of Lake Van (eastern Turkey). Geo$\log$ os 20, 79-87.

Valente, A., Slączka, A. \& Cavuoto, G., 2014. Soft-sediment deformation in Miocene deep-sea clastic deposits (Cilento, southern Italy). Geologos 20, 67-78.

Van Loon, A.J., 2009. Soft-sediment deformation structures in siliciclastic sediments: an overview. Geologos 15, 3-55.

Van Loon, A.J., 2014a. The life cycle of seismite research. Geologos 20, 61-66.

Van Loon, A.J., 2014b. The Mesoproterozoic 'seismite' at Laiyuan (Hebei Province, E China) re-interpreted. Geologos 20, 139-146.

Van Loon, A.J. \& Mazumder, R., 2013. First find of biogenic activity in the Palaeoproterozoic of the Singhbhum craton (E India). Geologos 19, 185-192.

Van Loon, A.J. \& Pisarska-Jamroży, M., 2014. Sedimentological evidence of Pleistocene earthquakes in NW Poland induced by glacio-isostatic rebound. Sedimentary Geology 300, 1-10.

Van Loon, A.J. \& Su, D., 2013. Deformed stromatolites in marbles of the Mesoproterozoic Wumishan Formation as evidence for synsedimentary seismic activity. Journal of Palaeogeography 2, 390-401.

Wan, T.F., 1992. Tectonic evolution and stress fields of Shandong Province. Shandong Geology 8, 70-100.
Wan, T.F., 1993. Tectonic stress field of the Meso-Cenozoic intraplate deformation in East China and its application. Geological Publishing House (Beijing), 69 pp. (in Chinese).

Wang, A.D., Zhou, Y.Q., Yan, H., Wang, R. Zhang, E.K. \& Wang, Z.Y., 2013. Characteristics of soft sediment deformation structures of the Early Cretaceous in Lingshai Island of Shandong Province. Journal of Palaeogeography 15, 717-728 (in Chinese with English abstract).

Wu, W.J., Zeng, Z.X. \& Zhu, W.G., 2005. Research on rheology gauge of fish-head boudin. Advances in Earthscience 20, 925-932 (in Chinese with English abstract).

Wheeler, R.L., 2002. Distinguishing seismic from nonseismic soft-sediment structures: criteria from seismic-hazard analysis. [In:] F.R. Ettensohn, N. Rast \& C.E. Brett (Eds): Ancient seismites. Geological Society of America Special Paper 359: 1-11.

Yin, X.L. \& Yang, T.N., 2005. Seismites in the Laiyang Group in the Jiaozhou-Laiyang Basin, Shandong Province, and their tectonic implications. Geological Reviews 51, 502-507 (in Chinese with English abstract).

Yuan, J., 2004. The property and geological significance of seismites of Paleogene in Huimin sag, Shandong province. Acta Sedimentologica Sinica 22, 41-46 (in Chinese with English abstract).

Zhang, W.Y., Ye, H. \& Zhong, J.Y., 1978. 'Fault-blocks' and 'plates'. Science of China (A) 2, 195-211 (in Chinese).

Zhang, Y.Q, Zhao, Y. \& Dong, S.W., 2004. Tectonic evolution stages of the Early Cretaceous rift basins in eastern China and adjacent area and their geodynamic background. Earth Science Frontiers 11, 123-131 (in Chinese with English abstract).

Zhang, Z.Q. \& Liu, M.W., 1996. Stratigraphy (lithostratigraphic) of Shandong Province. China University of Geosciences Press (Wuhan), 328 pp. (in Chinese).

Manuscript submitted 24 February 2014 Revision accepted 23 March 2014 